This is an electronic reprint of the original article. This reprint may differ from the original in pagination and typographic detail.

Author(s): Litmanen, Tapio; Kari, Mika; Kojo, Matti; Solomon, Barry D.

Title: Is there a Nordic model of final disposal of spent nuclear fuel? : Governance insights from Finland and Sweden

Year: $\quad 2017$

Version:

Please cite the original version:

Litmanen, T., Kari, M., Kojo, M., \& Solomon, B. D. (2017). Is there a Nordic model of final disposal of spent nuclear fuel? : Governance insights from Finland and Sweden. Energy Research and Social Science, 25, 19-30.

https://doi.org/10.1016/j.erss.2016.10.009

All material supplied via JYX is protected by copyright and other intellectual property rights, and duplication or sale of all or part of any of the repository collections is not permitted, except that material may be duplicated by you for your research use or educational purposes in electronic or print form. You must obtain permission for any other use. Electronic or print copies may not be offered, whether for sale or otherwise to anyone who is not an authorised user. 


\title{
Is There a Nordic Model of Final Disposal of Spent Nuclear Fuel? Governance Insights from Finland and Sweden
}

\begin{abstract}
This paper explores citizen participation in Swedish and Finnish regulatory processes for final disposal of spent nuclear fuel (SNF). Finland and Sweden are considered the most advanced worldwide in terms of SNF disposal plans. Our aim is to analyze the institutional waste management frameworks, focusing on the role of civil society organizations (CSOs); how laypeople and civil society organizations have been able to participate and contribute to radioactive waste licensing processes; and the nature of radioactive waste risk debates. We review official documents of the waste companies and nuclear safety authorities, plus information from civil society organizations and laypeople. Our theoretical framework takes a civil regulation perspective, which is oriented towards institutional issues. The analysis indicates that civil regulation of SNF is better established in Sweden than in Finland because of institutional arrangements and the more controversial nature of nuclear power in that country. Swedish civil regulation resembles a more liberal approach, whereas in the Finnish case technocratic domination is evident and therefore CSOs have been left to choose critical, confrontational and antagonist civil regulation strategies producing dispersed and random civil regulation. We conclude that due to differences in civil regulation there is not a Nordic model for SNF disposal.
\end{abstract}

Keywords: Civil regulation; Civil society organisations; Spent nuclear fuel; Finland; Sweden 


\section{Evolution of SNF management in Finland and Sweden}

Spent nuclear fuel (SNF) management in Finland and Sweden have long been praised as the most advanced among the nuclear powered countries, in both technical and social senses. On the technical side the development of the KBS-3 disposal concept has continued for decades and the main principle of the concept has remained almost the same for nearly 30 years (Sundqvist 2002; Kojo \& Oksa 2014). In Swedish and Finnish SNF management the ideology to govern social and political tensions is a mixture of transparency, openness, voluntarism, incentives, science communication and public engagement in policy making. However, in recent years skeptics have increasingly called into question both the integrity of the disposal concept and the effectiveness of the participatory process (Lehtonen 2010; Elam \& Sundqvist 2011; Kojo \& Richardson 2012; Andersson 2014; Litmanen et al. 2014; Kojo 2014).

Seemingly similar societal features such as consensual and apolitical decision-making styles and general trust in governmental and regulatory institutions in these countries, however, mask some fundamental differences. For example, Finland lacks the dramatic nuclear power history that Sweden has had. The 1980 national referendum on the future use of nuclear power in Sweden has been part of the controversy over nuclear waste (Sundqvist 2002). It led to a historical and disputed nuclear phase-out agreement, while in Finland initiatives concerning phase-out never gained enough political support, even though an anti-nuclear movement was active in the 1970s and 1980s. When the Finnish parliament rejected the application for a new nuclear build in 1993, the nuclear waste problem was the most frequently mentioned argument (Lammi 2009, 74). Since the late 1990s, Finnish energy policy has become more nuclear friendly as Parliament has approved three applications for new nuclear reactors whereas in Sweden the nuclear power companies have struggled with profitability of operating nuclear power plants e.g. due to a tax on installed capacity (Litmanen \& Kojo 2011; Ylönen et al. 2015; Norhstedt 2010). Both countries have continued pronuclear power policy after the Fukushima nuclear power accident of 2011 (Hakkarainen \& Fjaestad 
2012; Fjaestad \& Hakkarainen 2013). However, in Finland the implementation of this policy has been more straightforward than in Sweden.

National policies for management of radioactive waste has been an expert-driven exercise in many countries, but since the late 1990s, particularly due to local conflicts in site selection, the technically oriented approach has changed. This has been called a 'participatory turn' (MacKerron \& Berkhout 2009; Blowers \& Sundqvist 2010; Bergmans et al. 2014). In Swedish and Finnish radioactive waste management policy, public engagement has been discussed and developed particularly in the site selection processes for an SNF repository. Both countries have had siting conflicts (Lidskog \& Litmanen 1997). However, in Sweden public consultation has also been part of the research and development (R\&D) process of the safety analysis although effectiveness of participation has been criticized (Elam et al. 2010), whereas in Finland R\&D has been in the hands of experts only (Litmanen et al. 2014; Litmanen et al. 2016).

In Sweden the site selection process started in the 1970s, though due to strong local opposition the process was discontinued in 1985. The Swedish Nuclear Fuel and Waste Management Company (SKB) began feasibility studies in 1992, which were based on a flexible siting strategy. This meant that the studies were carried out in municipalities, which through their own initiatives had displayed an interest in investigations (Sundqvist 2002, 115; Elam et al. 2010). Therefore, voluntarism became the cornerstone of the Swedish site selection process. After consideration of alternative host municipalities the site investigations in 2002-2008 focused on two, so called nuclear communities, i.e. municipalities with nuclear facilities already located in their territory.

A clear difference between Sweden and Finland is the public participation initiatives taken by societal actors other than the SKB, such as the Dialogue Project by the Swedish nuclear safety authority and the Transparency Programme by the Swedish National Council for Nuclear Waste 
(Elam et al. 2010; Hanberger 2012.) Also, the candidate municipalities in Sweden have been more active in promoting public participation than in Finland.

In Finland the site selection process began in the early 1980s. The first test site for developing bedrock drilling and the first possible host municipality for the repository were announced by the nuclear power company Teollisuuden Voima (TVO) in the mid 1980s. At that time public participation was non-existing and the style was in line with the Decide-Announce-Defend (DAD) approach, meaning that local politicians were told about the site selection on very short notice and local residents were informed only once the site investigations had been initiated. The power company thought that the permission of landowner was enough for initiating site investigations. Local resistance, particularly after the 1986 Chernobyl accident, prompted TVO to reconsider its approach. However, the site selection strategy was not as significantly reformed as in the case of Sweden, where SKB adopted voluntarism based on existing nuclear communities in the site selection process. In the late 1980s TVO, the company responsible for site investigations started negotiations with local politicians in the potential host municipalities and improved local communication. Later communication became also more reciprocal as the company wanted to learn stakeholders' views and perceptions concerning the final disposal and its impacts. An important legislative change was passage of the Nuclear Energy Act in 1987, which gave veto power to the local council of the proposed host municipality. Public participation was a visible part of the Environmental Impact Assessment (EIA) procedure in the late 1990s, but it was criticized for ineffectiveness by local opposing groups and academics/researchers for instance due to narrow framing (Rosenberg 1999; Hokkanen 2002; 2007). Another argument for ineffectiveness was the benefit package negotiated between with the representatives of Eurajoki municipality and Posiva and TVO parallel to the EIA procedure behind closed doors (Kojo 2014; Kojo \& Richardson 2012). Thus, during the site selection process the style of public participation moved from the DAD approach towards a MUM (Mitigate-Understand-Mediate) approach. However, in the case of 
Finland, the success factors in siting are deemed to be based more on trust in safety authorities, representative decision-making, economic dependency and incentives and tolerance of nuclear power technology at the municipal level than the role of public participation (Kojo 2014).

Currently nuclear waste companies in both countries are advancing their plans to construct the first geological repositories in the world for SNF. The Finnish Expert Organisation in Nuclear Waste Management, Posiva Oy, submitted its construction license application for a final repository for spent nuclear fuel to the Government on 28 December 2012. The license was issued on 12 November 2015. The plan is to build the repository in Olkiluoto, Eurajoki. The Swedish SKB submitted its construction permit applications on 16 March 2011 to the Radiation Safety Authority (Strålsäkerhetsmyndigheten, or SSM) and to the Land and Environment Court to build the SNF repository in Forsmark, Östhammar. According to the schedule of the Environmental Court it will submit its statement to the government in February-June 2017 (MKG 2016a). The government will take the decision after that. Before the decision is made, approval will be sought from the host municipalities of Östhammar and Oskarshamn, which are both vested with veto power. It is possible that a local referendum will be arranged in Östhammar in 2017 (MKG 2016b).

Posiva's application for a construction license concerned a complex of two interconnected nuclear facilities - an aboveground encapsulation plant and an underground final repository. Both facilities will be located in Eurajoki. In Sweden, the final disposal repository and the encapsulation facility were applied for at two different sites - the encapsulation facility in Oskarshamn, and the underground repository in Östhammar. In both cases the handling of the application and review of the safety case is expected to take several years (Anderberg 2014).

The purpose of this paper is to scrutinize the role of civil society organizations $\left(\mathrm{CSOs}^{1}\right)$ in SNF management in Finland and Sweden. We will address this research question by comparing and contrasting institutional arrangements of SNF management in these countries, including public participation. While Sweden and Finland are commonly seen as success stories in implementing 
final disposal of SNF (e.g. Blowers \& Sunqvist 2010; Elam \& Sundqvist 2011; Hanberger 2012), we will highlight differences in how CSOs are integrated into the nuclear waste regimes and the licencing processes.

In the following section our theoretical framework will be introduced, underlining the perspective of civil regulation in parallel with state and market regulation. The next two sections will provide a brief overview of the institutional arrangements for risk regulation established for SNF management in Finland and Sweden. This will be followed by a discussion of the role of CSOs in the licensing processes in both countries. Finally, the paper will close with some conclusions, which indicate that the Swedish regime is more supportive of civil regulation than the Finnish framework. Furthermore, CSOs have better opportunities to participate in regulation in the Swedish licensing process than in the Finnish process.

\section{Civil regulation as a form of citizen participation}

Civil regulation as a form of citizen participation has not received as much attention from researchers as the participation itself. Several researchers as well as the Nuclear Energy Agency have acknowledged that public participation and 'participatory' processes in SNF management are important (NEA 2000; 2013; Lidskog \& Andersson 2001; Bergmans et al. 2008; Blowers \& Sundqvist 2010; Elam \& Sundqvist 2011; Bergmans et al. 2014; Kojo 2014). Even so, a critical assessment of the so called participatory turn, or regular, transparent, two-way dialogue has indicated that the technocratic elite sets boundaries that cannot be crossed (Elam \& Sundqvist 2011; Bergmans et al. 2014). Both in Finland and Sweden regulatory regimes resemble fairly conventional state-centric arrangements, where dyadic relationships between the industry and the regulator are the norm, leaving almost no room for civil society actors (see Wahlström 1999, 52-53; Litmanen et al. 2016). Therefore, it is important to analyze civil regulation in SNF management.

Civil regulation strategies can vary, but two main ones have been identified. Liberal strategies aim at engagement, reform of business practice and often make use of market mechanisms to 
incentivize and achieve change, whereas critical strategies are more confrontational, employ protest tactics and pose more fundamental challenges to business-as-usual activities (Newell 2008, 141). Advances in the study of regulation can take place if both the liberal and antagonist strategies of CSOs and civil regulation are considered more explicitly in the theoretical model of regulation. Vogel (2010) has noted that there are already important linkages between civil and state regulation ${ }^{2}$ (Vogel 2010, 69-72), but other researchers have stressed the importance of distinguishing CSOs from state regulatory authorities, and also from private enterprises (Williams et al. 2011a). For Beierle \& Cayford (2002) the term civil regulation refers to initiatives coming from outside of the institutionally managed public engagement, where organizations consult with interested or affected individuals, organizations and government entities before decision making (Beierle \& Cayford 2002, 6). Also Bendell (2000) and Murphy \& Bendell (1999) stress how civil regulation includes more self-initiated and unprompted form of action by the civil society, where CSOs question the preset political agendas, participate in setting the standards for corporate behavior and try to affect the political-economic context within which business and governmental authorities must operate (Bendell 2000, 246; Murphy \& Bendell 1999, 46).

Researchers have tried to define this conceptual innovation in different ways. Some authors emphasize the importance of understanding how civil society tries - by exerting pressure - to persuade or even compel organisations to align their behaviour better with the prevailing societal concerns (Bendell 2000a; see also Murphy and Bendell 1999; Vogel 2010; Williams et al. 2011a, 2011b). Pellizzoni (2004, 558), for instance, argued that pressure coming from the civil society is directed towards private enterprises. He emphasized the overall right of civil society actors to exercise social control over built capital, for example, by protesting. Some scholars lay greater emphasis on the relationship between institutionally established regulation and civil regulation. In such a case, the focus is on how civil society actors' attempt to assess how well the regulatory state is promoting public ends, using various kinds of expertise (local knowledge, scientific, etc.) or how 
citizens as consumers, customers or workers try to influence regulatory agencies and to exercise their own forms of regulatory control (Hochstetler 2012, 363). Besides these types of attempts of civil society actors to directly influence the regulators or the licence holders there are also attempts to influence what can be called 'meta-regulation'. For example, Ringius $(1997,62)$ has analyzed how environmental non-governmental organizations (ENGOs) performed a crucial role in changing the rules, norms and principles of the global radioactive waste regime for ocean dumping. For him, ENGOs function primarily in four ways affecting regulation: mobilizing international public opinion, building transnational coalitions, monitoring states' environmental commitments, and advocating precaution and protection of the environment (Ringius 1997, 63-65; see also Aldrich 2012). Also Meserve (2009) and Alger \& Findlay (2010) include CSOs as actors providing important stimulus for change in the nuclear power risk regulation regime.

According to Hutler \& O’Mahony $(2004,8)$, CSOs can have great potential as regulators as they 1) encourage the development of ethics, 2) push organizations to behave in a socially responsible manner, 3) democratize regulation in corporatistic tripartite settings, and 4) intervene in dyadic relationship between the regulator and the regulated. The authors note that CSOs can contribute to several key regulatory areas as knowledge providers, watchdogs, auditors and ruleenforcers, but also can create innovative ways of thinking about and approaching regulatory problems (ibid, 9).

However, these benefits of civil regulation are counterbalanced by challenges such as 1) representativeness and independence of CSOs, 2) CSOs' accountability and transparency, 3) trustworthiness of CSOs' expertise and their knowledge, 3) CSOs' dependence on public or private funding sources, and 4) a loss of coherence in regulation due to decentralization of regulatory power (Hutler \& O’Mahony 2004, 9-12). Also, Krieger and Rogers (2010) have warned about putting too much trust in genuine collaboration between CSOs and other actors as a means of replacing stable, legitimate and authoritative forms of traditional government. They also pour cold water on 
arguments that 'social' or 'civil' regulation through partnerships can substitute for other forms of regulation or that partnerships are a strong tool to solve different problems (Krieger \& Rogers 2010, 926; see also Jasanoff 1985, 20-21; Bendell 2000, 252-253). Furthermore, regulators themselves have emphasized political, financial and technical independence of the regulator, although they also admit that "appropriate stakeholder involvement within decision-making processes provides the opportunity to obtain a broader basis for decisions which can also contribute to the regulatory body's improved credibility in society." (NEA 2014, 15) ${ }^{3}$.

In the case of nuclear waste management civil regulation can have at least three aims: 1) trying to influence activities or self-regulation of those responsible for implementing nuclear waste disposal, 2) trying to influence practices and management of regulatory agencies and 3) trying to influence meta-regulation, i.e. preparation, renewal and updating of national and international rules, norms and principles guiding the implementation of regulation. We define civil regulation as activities performed by CSOs and individual citizens, pushing either corporations or public authorities to deliver improvements in their regulatory standards or activities, and developing nonstatutory norms, codes and standards of good practice that are intended to govern nuclear safety (Williams et al. 2011a, 954; Williams et al. 2011b, 45; Hood et al. 2003, 23; Jasanoff 1985, 20-21). Thus, at its best, civil regulation can help to develop national and transnational regulatory schemes both inside and outside normal institutional settings.

Next we will focus on the Finnish and Swedish institutional settings in which civil regulation takes place. Special attention is paid to Finnish and Swedish repository licensing processes, which is the backbone of SNF regulation. In our view, institutional setting can either support or hinder civil regulation". For instance, Williams et al. (2011, 966-967) emphasize the importance of understanding the complex regulatory environment and existing legislation when analyzing how civil regulation functions. 


\section{Institutional settings of Finnish and Swedish risk regulation regimes}

Interventions of CSOs in the field of nuclear safety regulation are made very difficult due to institutional closures. For instance, in Finland legislation and institutional arrangements strengthen the prominent role of the central actors, the Radiation and Nuclear Safety Authority (Säteilyturvakeskus, or STUK), the nuclear industry and the Ministry of Employment and Economy (MEE), with little or no opportunity for public participation (Litmanen et al. 2014, 8). Findings of Reiman et al. (2010) also indicated that there are few core players in the field of nuclear safety. The parties affecting the nuclear safety culture are industry, the government administration and technical support. Other players the interviewees mentioned were rescue service organizations, police, nuclear waste management organizations and consultants, but not any civil society organizations (Reiman et al. 2010, 31-32). However, the media was mentioned affecting the development of safety culture. Some interviewees, while downplaying the importance of the media, perceived it as a counterforce that improves the conditions for action by CSOs (Reiman 2010, 33). Institutional closure to civil regulation has also socio-historical reasons. As Wärnbäck (2012) and Litmanen et al. (2016) indicate, sustained interaction with the implementer and the regulator in Finland and Sweden has created convergence between the parties (see also Wärnbäck et al. 2013; Elam and Sundqvist 2009). This can help create shared values and priorities amongst the involved parties.

There are different kinds of institutional arrangements established in different regimes for SNF management (NWTRB 2009, 2011). A survey by the U.S. Nuclear Waste Technical Review Board (NWTRB 2009) identified 15 key attributes related to these arrangements. Next we will describe some of the similarities and differences in the institutional settings of the Finnish and Swedish risk regulation regimes in order to provide an overview of how the stage is set, i.e. the context in which licensing is done and CSOs operate. Attributes considered, some briefly and others in more detail, in this section are: (1) legislation (defining responsibilities); (2) organizational form of the implementer; (3) independence of the regulator; (4) independence of technical/program 
oversight; (5) state nuclear waste funds; (6) selection of the waste management option; (7) site selection; (8) environmental impact assessment; (9) local veto; (10) limitations on local veto; and (11) community benefits. Attributes considered in Section 4 will include: (12) different decision stages and (13) necessary approvals required by the regimes, after the implementers have concluded their siting process. We have analyzed licensing processes separately to highlight them, because they are central from the perspective of civil regulation.

Finland and Sweden share not only similar institutional arrangements, but also a similar geology. Furthermore, interaction and cooperation in the area of nuclear technology transfer have taken place since the Finnish utility Teollisuuden Voima (TVO) acquired two nuclear power plant (NPP) units from the Swedish ASEA Atom in the 1970s (Sunell 2004; von Bonsdorff 2007). Partly because of these previous connections the Swedish final SNF disposal concept, i.e. KBS-3, was also adopted in Finland. Thus, currently Finland and Sweden share the same disposal concept and the SKB and the Posiva are collaborating in R\&D of the concept (Kojo \& Oksa 2014a).

Legislation and treaties are the cornerstones of institutional settings. In Finland, SNF management is regulated by the Nuclear Energy Act of 1987 (11.12.1987/990) and its amendments in 1994 (amended by Act 1420/1994), 2003 (amended by Act 1131/2003) and 2008 (342/2008), and the Nuclear Energy Degree of 1988 (STUKLEX 2015). According to the Nuclear Energy Act "[a] licensee whose operations generate or have generated nuclear waste (licensee under a waste management obligation) shall be responsible for all nuclear waste management measures and their appropriate preparation, as well as for their costs (waste management obligation)." The Nuclear Energy Act also defines the licensing process for a nuclear facility, such as the final radioactive waste disposal repository.

In Sweden, according to the 1984 Act on Nuclear Activities (SFS 1984, 3) ${ }^{4}$ parties holding a license to possess or operate a nuclear power plant (NPP) are also responsible for ensuring that the necessary comprehensive R\&D work is conducted to guarantee fulfillment of safe management and 
domestic geologic disposal of SNF from Sweden's NPPs (Elam \& Sundqvist 2011, 250-253). License holders are also responsible for bearing the costs. However, in Sweden there is another relevant law, i.e. the Environmental Code (SFS 1998:808), which the waste disposal concept must comply with. This duality has its own bearing on the licensing process which will be examined later. Overall, the Swedish institutional arrangements produce a more complex licensing and planning process than the Finnish ones.

\subsection{Similarities in institutional settings}

There are several basic premises that are similar across the regimes (see Table 1.). In both countries the licensees are responsible for waste management measures, preparation of implementation and costs, and the organizational form of the implementers of SNF management is similar, i.e. Posiva in Finland and SKB in Sweden are both private corporations formed by the companies owning NPP units.

[Insert Table 1. Here]

Posiva was established in 1995 by TVO and the state owned power company Imatran Voima (IVO) following the amendment of the Nuclear Energy Act in 1994, forbidding the export of SNF. However, it should be noted that in Finland the new power company, Fennovoima, which received an approval to build a new NPP unit in 2010 (Litmanen 2010), is not a shareholder of Posiva. Because of difficulties in creating collaboration between Fennovoima and Posiva it is possible that a second SNF repository will be needed in Finland (Kojo \& Oksa 2014b; MEE 2012; 2013).

The Swedish counterpart to Posiva was established much earlier, in 1972, but the initial task of the company was not SNF management. The Swedish Nuclear Fuel Supply Company (SKBF) was created as a joint venture between the country's NPP owners to coordinate inflow and outflow 
of reactor fuel at the national level, and to keep the fuel cycle smooth as new reactors were commissioned. After the passage of the Act on Nuclear Activities in 1984, following the decision to phase out nuclear power in Sweden in 1980, SKBF was transformed into SKB (Elam \& Sundqvist 2011, pp. 250-253).

In both countries government regulators, i.e. STUK in Finland and SSM in Sweden, have similar duties as they set safety regulations, and bear responsibility for reviewing implementers' R\&D and demonstration programs, and license applications. Both Posiva and SKB have their own R\&D and demonstration programs ${ }^{5}$ (SKB 2010; Posiva 2013b; see also SSM 2011a; Litmanen et al. 2014).

The Swedish radiation safety regulation was reorganized as the SSM was established in 2008 by merging the Radiation Protection Institute and the Nuclear Power Inspectorate. STUK falls under the supervision of the Ministry of Social Affairs and Health, whereas SSM operates under the supervision and auspices of Ministry of the Environment (ME). Both STUK and SSM (and its predecessors) have attempted to develop good communications and interactions particularly with local publics at potential host communities. Thus, regulators have to some extent adopted a participatory turn, although at the same time STUK has also sought to strengthen the power of experts in SNF policy (Sundqvist \& Elam 2010; Kojo 2014). For instance, STUK has agreed with the MEE and Posiva that more decision-making power regarding technical solutions should be granted to them, instead of the government (Litmanen et al. 2014; Kojo 2014; for Sweden see Wärnbäck 2012; Wärnbäck et al. 2013). Consequently, the Government amended the Nuclear Energy Act in 2015, which strengthened STUK's power as a fully independent regulatory body, but at the same time it reinforced a highly technocratic style of decision-making.

Both countries have also established an SNF management fund - the State Nuclear Waste Management Fund (Valtion ydinjätehuoltorahasto) in Finland, and the Nuclear Waste Fund (Kärnavfallsfonden) in Sweden (MEE 2015; Kärnavfallsfonden 2015). 
In Finland, the parties liable for SNF management produce annually an estimate of the costs. On the basis of these estimates, the MEE decides on liability for outstanding payments and enforces the annual payment obligations based on the calculations. Once a year, licensees pay the difference between the Fund target and amount existing in the Fund. Thus, the Fund is guaranteed ${ }^{6}$. Payment can be made in securities, and money is returned if payments exceed total liabilities. However, at all times the total value of the assets in the Fund must correspond to the costs of SNF management interventions not yet completed. Annual payments collected in the fund also include R\&D costs, and other costs mandated by the authorities and administration (MEE 2015; NWTRB 2009, p. 26).

In Sweden the owners of NPPs pay a fee based on the estimated costs of disposing SNF. The fee varies each year, and varies as well from one NPP to another. The Swedish government decides on the fee level based on a recommendation by SSM. Owners guarantee coverage of the difference between payments into the Fund and the total estimated cost of SNF disposal.

In both countries the focus of repository siting moved from a search for the geologically best site to a search for the most suitable site from a socio-technical perspective, and ended up with already existing nuclear communities. An EIA for the facilities has been conducted in both countries. In both countries the proposed host community has been vested with veto power over site selection according to the law. In both countries waste management companies have also entered into benefit package with the local communities providing community benefits in order to make siting more acceptable.

\subsection{Differences in institutional settings}

While both Finland and Sweden have adopted principles of national responsibility regarding the final disposal of SNF, the legislative frameworks of the two countries differ from each other (see Table 1.). 
In Finland, the IVO had agreed with the former Soviet Union to purchase uranium oxide fuel needed to run its NPP units and to return the spent fuel there. After the collapse of the Soviet Union in the early 1990s, this arrangement was deemed inadequate. Furthermore, as Finland was joining the European Union (EU) it was considered important to ensure that that SNF management would remain under domestic control. Hence, before Finland joined the EU, the Finnish Nuclear Energy Act was amended in 1994 to ban both export and import of SNF (Alanen 1994; Kari 2015).

In Sweden, the principle of national responsibility was formulated in the beginning of $1980 \mathrm{~s}$ in connection with the development of a national nuclear waste policy. According to this policy, all SNF from Swedish sources should be disposed in Sweden and foreign waste should not be received. The principle was, in a way, given legal expression in the Nuclear Activities Act in 1993, when disposal of foreign spent nuclear fuel was banned. Export of spent nuclear fuel was not, however, forbidden. While the law was amended to forbid also interim storage of foreign SNF and export to countries listed in the Radiation Protection Act, there is still no categorical ban on exporting SNF from Sweden (Cramér et al. 2007, 25-26, 29-33).

One of the main differences between the Finnish and Swedish risk regulation regimes is the absence, in Finland, of a technical/program oversight carried out by an entity independent of the implementer and the regulator (NWTRB 2009, 14). In Sweden, the National Council for Nuclear Waste (Kärnavfallsrådet est. 1992, previously known as KASAM) advises the ME. According to the Council, its 'assignment is to investigate and clarify matters relating to nuclear waste and decommissioning and dismantling of nuclear facilities'. Besides giving advice to the Government, the Council serves as a knowledge base for other stakeholders and organizes annual seminars. The aim is to 'identify and investigate issues of importance in the field of radioactive waste, as well as to create an arena for different stakeholders in Sweden to meet and communicate. International seminars are also important components in the dialog to gain new knowledge and to get their view of the Swedish process' (Kärnavfallsrådet 2015). 
As noted earlier, both Finland and Sweden have established an SNF management fund. However, there is one important difference between these funds. Unlike in Finland, in Sweden fund assets may be used to reimburse a candidate municipality for information costs and to support nonprofit organizations. There are limitations to the funding, e.g. reimbursement may not exceed SEK 10 million (1190000 $€^{7}$ ) per municipality over a 12-month period, and support for nonprofit organizations may not exceed SEK 2.5 million $\left(297500 €^{8}\right)$ per organization per calendar year and SEK 3.5 million (416500 $\left.€^{9}\right)$ in total per calendar year. In 2013 the disbursements amounted to SEK 12.7 million (circa 1,51 million $€^{10}$ ) and support for nonprofit organizations was SEK 3.5 million (Kärnavfallsfonden 2013, 18; NWTRB 2009, 42).

As mentioned earlier EIAs have been conducted, but the way their status in the licensing processes differed. In Finland, the EIA process was a higher-profile event explicitly designed as a showcase of the new participatory approach (Hokkanen 2007; Kojo 2014), whereas in Sweden, the EIA did not attract the same attention, and wasn't perceived as the most important instrument of public participation (Johansson 2008; Elam et al. 2009; 2010). While in both countries the proposed host community can veto the repository site selection, according to Finnish legislation the government cannot override a local veto, while in Sweden an override is theoretically possible by law (NWTRB 2009, 28, 44; Bjällås \& Persson 2013, 31-32). Also, in Finland, the host community's positive statement is required early in the licensing process, before the Council of State can grant a Decision-in-Principle (DiP) for a nuclear facility, whereas in Sweden permissibility is granted later when an application for permission to construct a SNF repository is processed. As the plans for municipal referendum in Sweden indicate, the municipality is able to withdraw until the last minute before the government decision on permissibility. The licensing processes are compared later in more detail. The last of the institutional settings examined in this section relates to compensation and community benefits. As also noted earlier, in both countries benefits are provided to the local communities by implementers, but arrangements vary greatly. In Sweden the municipalities of 
Oskarshamn and Östhammar negotiated the Added Value Program, worth approximately $200 \mathrm{M€}$, with the Swedish nuclear industry. In Finland the municipality of Eurajoki negotiated a compensation package with Posiva and TVO. The Finnish package, consisting of loans and other agreements, was far more modest compared to the Swedish arrangement, but in addition the municipality of Eurajoki receives annual tax revenues. The fact that the Eurajoki did not demand a more substantial support package can be partly explained by the interest of the municipality to locate a new NPP unit, which yields additional annual tax revenues (Litmanen \& Kojo 2011; Kojo \& Richardson 2012). Moreover, in Finland arrangements related to community benefits were more like a competition between two 'nuclear oases' (Blowers 1999), whereas in Sweden the two host candidates were able to collaborate to some extent in negotiations with the nuclear industry.

\section{Licensing processes in Finland and Sweden}

While final SNF disposal plans in Finland and Sweden may nominally seem to be in the same phase, since in both countries construction license applications were submitted around the same time, in reality the situation is not so straightforward. In Sweden, SKB chose a site for the repository (and for the encapsulation facility) in 2009 but the government has yet, in compliance with the Environmental Code (SFS 1998:808), to decide on the permissibility of the repository. Both Oskarshamn and Östhammar have a chance to veto and reject the activity planned within their municipality (Michanek \& Söderman 2008). In Finland, however, the site for the repository was more firmly decided in 2000 when the Council of State granted the DiP to Posiva, once the municipality of Eurajoki had first issued a positive statement regarding the repository, thus choosing not to use its veto power granted by the Nuclear Energy Act (Kari et al. 2010, 17).

As a result of already existing political decisions from the government, the remaining licensing process after the application is intrinsically more straightforward in Finland than in Sweden, although serious technical questions regarding the KBS-3 concept in the Swedish review 
process could affect the Finnish process too. In general, Finnish nuclear legislation defines a threestep authorization process: 1) the Decision-in-Principle (DiP); 2) the construction license issued by the Council of State; and 3) the Operating License, also issued by the Council of State. Before the government passed the DiP to Parliament for ratification, the STUK gave a positive statement on the grounds of its preliminary safety appraisal (Ruokola, 2000; Vuorinen 2008). This means that the company passed the first milestone in 2001. The last two licensing decisions are of purely administrative nature even though they will be made exceptionally by the Council of State. The perfunctory nature of these decisions can be seen in the way that Posiva has interpreted the decisions. Posiva is arguing that as long as it passes the safety assessment carried out by STUK, the licensing decision should be a mere routine administrative issue (Posiva 2009).

Nevertheless, since the MEE prepares decisions for and presents issues to the government, the applicant has to pay close attention to considerations of the MEE. The next licensing stage in SNF management, after the construction license, in Finland will concern the operation license. Posiva plans to submit the operating license application in 2020 for possible repository commissioning in the 2020s (Posiva 2015).

SKB, in turn, has submitted three license applications. Two were submitted to SSM based on the Nuclear Activities Act and Radiation Protection Act for the repository and the encapsulation plant, and another one according to the Environmental Code to the Environmental Court for the whole repository system (Persson 2011; NEA 2011, p. 8). Therefore, SKB has to work with two parallel processes. Compared to Posiva, SKB has to face a more complex process, as its plans have to satisfy the Environmental Court, and the municipal councils have to accept the operations so that the government can grant permissibility. After permissibility is granted, the Environmental Court has to hold a hearing and decide on the permits and conditions according to the Environmental Code $^{11}$. In the later stages, after the construction license, SKB would have to get approvals for starting construction, for test operations, and for routine operation ${ }^{12}$. 
Originally, despite this greater complexity in the construction licensing process and the fact that SKB needed approval from five different organs (the Swedish Radiation Safety Authority, the Environmental Court, the municipality of Oskarshamn, the municipality of Östhammar and the central Government), the company nevertheless expected that the application process would progress shoulder to shoulder with Posiva's in such a way that construction of the disposal facilities could begin in 2015 and final disposal could start in 2025. In reality, the Council of State granted the construction license for the Finnish SNF repository on 12 November 2015 after STUK had stated in February 2015 that the SNF facility can be built to be safe (STUK 2015). In Sweden, SSM released its own statement in connection with STUK's statement ${ }^{13}$, noting that it would submit its conclusions regarding SKB's application in 2017 (SSM 2015).

\section{Involving the civil societies}

The design of the Finnish regulatory regime excludes the impact of the CSOs almost completely from the last two out of three licensing phases. The regulatory regime can be described as approaching more of a full-blown closed technocratic system focused on information dissemination, instead of giving and providing opportunities for participation and deliberative processes, not to mention possibilities to review the applications and the documents. The involvement of civil society and CSOs regarding the final disposal focused on the siting phase (Hokkanen 2007; Kojo 2014) and diminished after the DiP. After that, dialogue has been truncated to discussion between the safety regulator STUK and the applicant Posiva, overseen by MEE government officials (Litmanen et al. 2014). Public meetings regarding the expansion of the repository in 2008-2009 attracted few participants (Nurmi et al. 2009). Local residents are given the role of objects of pro-nuclear storytelling (Yli-Kauhaluoma \& Hänninen 2014). The EIA for the DiP was an instrument, which opened possibilities for CSO actors, but very limited ones. Hokkanen concluded that the EIA and its participation processes 'drowned' in pre-designed planning and decision-making processes. 
Participation of CSO actors in EIA was far from ideal, because the EIA was only an appendix when the government and parliament handled the issue (Hokkanen 2002, 34-35; Lehtonen 2010, 190).

In Finland, CSOs have a great challenge in raising SNF issues in the media partly because the journalists tend to turn to more institutional established actors such as the company and the regulator. For instance, the former director of STUK, Jukka Laaksonen, has emphasized the importance of 'training' journalists in advance. In particular, STUK has held courses for journalists to inform them of nuclear power issues (see Lehtinen \& Isaksson 2007). According to a Nuclear Energy Agency report, Laaksonen has concluded that STUK gained a position as a trusted source, meaning that in the event of a story, the journalists ask for STUK's view (NEA 2009, 26). Also, Posiva is considered by journalists to be a trusted source (Tommola 2001) ${ }^{14}$. Furthermore, local activists have complained that it was hard to find independent expertise in a small country like Finland where almost all the experts were somehow connected either to the industry or the regulatory authorities (Rosenberg 1999, 267).

The problem of getting themselves heard is recognized by CSOs. For example, three Finnish CSOs have expressed concerns that decision-making for the SNF repository construction license is seemingly becoming a case without democratic public debate. CSOs such as Women Against Nuclear Power, Still No to Nuclear Power Citizen Movement, and Women for the Peace in Finland, have tried to draw people's attention to what they consider as serious technical and ethical problems related to final SNF disposal project. They state that the public debate in in Sweden is more democratic and open on the KBS-3 concept, whereas in Finland the debate is non-existing (Klötzer et al. 2013).

In Sweden, the CSOs observing SNF management are in a better position compared to CSOs in Finland. Johan Swahn, director of the MKG (Miljöorganisationernas kärnavfallsgranskning) ${ }^{15}$, has stipulated three conditions for meaningful participation: 1) a real possibility for changing things if the organisation in question considers that there are reasons for concern; 2) an arena for 
consultation that is less constricted and controlled than a formal consultation process associated with a repository license application; and 3) adequate resources for participation (Swahn 2011, 13). Swahn seems to agree with the notion that in Sweden these conditions have, at least to some extent, been met (see also Johansson 2008).

However, it would be a fallacy to consider the Swedish model of integrating CSOs in SNF regulation as ideal solely based on opportunities for public participation and funding for CSOs. Kåberger and Swahn $(2015,223)$ have critically evaluated the Swedish SNF management model calling for reforms, which could include, e.g. more possibilities for funding for independent research and development work and critical evaluation of the industry's work. Elsewhere the Swedish model has been called 'delegated democracy', because of the large degree of delegation of the preparation work to sub-political actors and $\operatorname{arenas}^{16}$, and the marginal role of political decision making and parliamentary arenas (Johansson 2008, 392).

A fundamental difference of Sweden compared to Finland is the annual opportunity for CSOs to apply for funding (OECD 2011, 12-13; Swahn 2011, 1-4). As noted in a comparative study on non-governmental organizations (NGO) involvement in radioactive waste management in different countries, '[i]n Sweden any NGO of a certain size can apply for funds from the Swedish Waste Fund to monitor and become interested in the final repository project' (NDA 2010, 13). For instance, the Swedish NGO Office for Nuclear Waste Review (MKG, Miljöorganisationernas kärnavfallsgranskning) was created by the Swedish Society for Nature Conservation (Naturskyddsföreningen ) to work on nuclear waste issues and receives funding from the Swedish Nuclear Waste Fund to participate in the consultation process for a proposed Swedish repository for SNF near the Forsmark nuclear power plant (Swahn 2011).

However, the Swedish institutional settings have been reformed along the way. At the start of the 1990s there was a change in SKB's siting strategy as it was forced, because of social conflicts associated with test drillings, to abandon the idea of systematic geological research to identify the 
optimal site for the repository (Sundqvist 2002) ${ }^{17}$. In the early 1990s SKB started to apply a voluntary approach for siting. Anticipating a crisis, SKB turned to communities already hosting nuclear facilities (i.e. nuclear oases). Oskarsham, one of these communities, was able to ensure substantial resources for community involvement for those volunteering for the siting process and this shifted focus of the process closer to the local level (Elam \& Sundqvist 2007b, 8, 49; COWAM 2003, 18). National CSOs had earlier been left out of the process after a 'dialogue project', which was held for gaining a common view regarding the decision-making process, in 1990-1992 (COWAM 2003, 19; Elam et al. 2009, 31). SKB 'took the opportunity to run their own show with the feasibility studies' (COWAM 2001, 45), and the CSOs did not have the opportunity to get involved anymore, except through local groups ${ }^{18}$ (COWAM 2003, 19; COWAM 2001, 45). Additionally, the national CSOs argued that because of inadequate resources they were unable to act independently, to keep up with reports and meetings, and especially to hire their own experts who could increase their knowledge and competence, and could contribute to the siting and decision-making processes (COWAM 2003, 19). Furthermore, CSOs had concerns regarding the municipalities' position as guardians in the process (COWAM 2001, 62).

All the more worrisome from the CSOs' point of view was that they were not able to participate in common dialogue in the same arena as others. SKB's regional consultations and public consultation meetings for local citizens were not open to all parties, and CSOs were also excluded from the expert meetings between SKB and the authorities (COWAM 2001, 45; Elam et al. 2009, 25).

However, over a decade ago the situation changed. In 2004, the Swedish government decided to change the Nuclear Financial Act so that CSOs could participate in the process and receive financial support from the Nuclear Waste Fund (Elam \& Sundqvist 2007a, 58). In Sweden the CSOs, which observed Swedish SNF management, were now in a better situation than earlier and compared with their counterparts in Finland, where no annual funding is available for CSOs. 
However, in April 1999, just before Posiva submitted its DiP application, the Ministry of Trade and Industry granted a lump sum of 206000 FIM (circa $45500 €^{19}$ ) for five different CSOs for communication activities regarding final disposal of spent nuclear fuel. Most of this funding (170000 FIM, circa $37500 €^{20}$ ) was allocated to the Finnish Association for Nature Conservation, which published a report on problems regarding final disposal of SNF (Richardson 1998). The rest of the funds were received by local groups.

In 2005, SKB, after critique and pressure from CSOs, opened the regional consultations to the public and CSOs have also been able to attend the public consultation meetings directed at the local citizens. Moreover, in 2006, The Swedish Nuclear Waste Council started a 'transparency programme', a descendant of the dialogue project from 1990-1992, which identified a need for a broader set of actors to participate and accordingly included CSO representatives (Elam et al. 2009, 23, 36; Hanberger 2012). Unfortunately, CSOs quickly learned that opening up of regional and citizen consultations did not always mean opening up to real participation and influence, which frustrated CSO representatives (Elam et al. 2009, 25). A critical assessment of SKB's public consultation processes also shows that SKB organized the public in a way that 'can be said to subdue rather than support broader public dialogue'. As Elam et al. (2010) have indicated, the original SKB model is one that should be taken for granted and cannot be called into a question by the public, even in the cases of public consultations (Elam et al. 2010, 203).

\section{Conclusions}

The aim of this paper was to analyze Swedish and Finnish regulatory processes for final disposal of SNF, paying special attention to the role of civil society. The comparison of Finnish and Swedish regulatory frameworks in SNF management from the viewpoint of civil regulation has revealed that important differences can be found in how CSOs and citizens are involved in discussing key issues. The fundamental difference is institutional by character, with Sweden having a more permissive ${ }^{21}$ 
and complex design than Finland. In Finland the dominant view held by both the STUK and the implementer is that after the DiP in 2001 extensive, in-depth public dialogue is unnecessary, and therefore more advanced engagement methods have not been developed, not to mention civil regulation arrangements. The review process regarding the repository construction and operation license applications is perceived as primarily technical, whereas the DiP review is deemed as more political.

We conclude that these countries are on different tracks in relation to public engagement and that there is no solid Nordic socio-technical model to follow in final disposal of SNF. Although the KBS-3 technical concept is applied in both countries, the way of addressing the social dimension has clear country-specific features.

The idea of separation between the social and the technical aspects of SNF management is in line with observations by Bergmans et al. (2014), who examined the importance of how technical and social issues are combined in planning and decision-making regarding SNF management. The Finnish process leans heavily towards separation of the technical and social. The DiP is the societal phase of the process, since for the DiP the Council of State judges if the project is in line with the

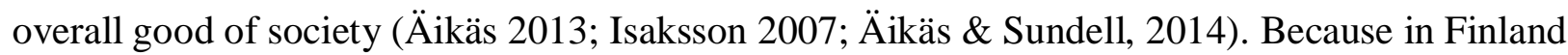
this decision is made early, the host community only has the opportunity to review the general outlines of the SNF repository and the preliminary safety assessment. By contrast, the Swedish process seems to combine technical and social issues better, as the proposed host municipality has a chance to review the full technical documentation of the applications before deciding on the use of veto power.

As a result of the Swedish way of public participation and civil regulation the decisionmaking process is more complex than in Finland, unpredictable and not easily manageable. Nevertheless, as a result of a complex, multilayered and multi-phased process the outcome can be a 
socially more stable and lasting decision. The democratization of technology may need extra time and resources invested in the process.

All the power in Finland is in the hands of the regulatory authority, STUK, which is now engaged in risk dialogue with Posiva (Litmanen et al. 2014; 2016). CSOs complain that it is very difficult to raise important issues onto the public agenda. For instance, in the case of the Swedish debate on copper corrosion, which is based on a scientific dispute between independent scientists and SKB, there has been little interest by the Finnish media (Andersson 2014; Litmanen et al. 2014). By contrast, in Sweden, the National Nuclear Waste Fund provides funding to CSO in order to encourage these to conduct their own analysis of SNF management. Because of their resources, Swedish CSOs are more able to pressure on SKB and government authorities, even though their contribution to some consultation processes or public meetings is not always desired.

Our analysis has indicated that civil regulation of SNF is better established in Sweden than in Finland, and because of institutional arrangements it has more opportunities to affect legal and administrative processes. Swedish civil regulation more closely resembles Newell's liberal approach, in which the regulatory regime is partially open to initiatives from civil society and also resourced by the system (Newell 2008). Finnish CSOs trying to fulfill a civil regulation task are forced to operate outside the regulatory processes without any possibilities to influence either the licencing process or to participate in the review of Posiva's research, development and technical design processes conducted by STUK. The CSOs have no other option than to adopt a confrontational and antagonist civil regulation strategy (Newell 2008). In order to avoid a complete technocratic domination in the regulatory processes, we emphasize the importance of increasing CSOs' abilities to participate in risk regulation by providing them with adequate funding and possibilities to produce critical inspection of the plans and studies of the disposal of SNF.

Civil regulation can provide a useful contribution to the activities of the regulated, on practices and management of regulatory agencies and on meta-regulation governing the whole 
regulatory setting. We suggest that in order to increase laypeople's eagerness to participate and provide opportunities to democratize risk regulation, nuclear regulatory processes should be analyzed more than has been done before from the perspective of civil regulation. Future research could also chart the historical development of nuclear regulation institutions, especially considering the close relationships between industry and regulation. We also emphasize the importance of addressing key questions related to civil regulation such as expertise, competence, responsibilities and overall applicability of civil regulation.

\section{Acknowledgements}

The authors acknowledge the financial support of the Academy of Finland (research project no. 253332) and the Finnish Research Programme on Nuclear Waste Management (KYT) 2015-2018 for the research on which this article is based. We would also like to thank the four anonymous referees for their insightful advice and suggestions for improving this manuscript.

\section{References}

Äikäs T. 2013. The Finnish nuclear waste management programme: experience, status and views on the future. Posiva Oy. Presentation Given at The Stockholm Talks 2013, $2^{\text {nd }}$ October 2013, Stockholm, Sweden.

Alanen, J. 1994. Suomen EY-jäsenyyden vaikutukset: ydinjätteiden ja muiden radioaktiivisten jätteiden tuonti. [Impact of Finland's membership in the EU: import of nuclear and other radioactive wastes.] Ministry of Trade and Industry, Helsinki.

Aldrich D.P. 2012. Civil society rising. Bulletin of the Atomic Scientists. Web-edition. 9.3.2012. http://thebulletin.org/web-edition/features/civil-society-rising -- Accessed 28 December 2015

Alger J., Findlay T. 2010. Strengthening global nuclear governance. Issues In Science and Technology 27 (1), 73-79.

Anderberg, J. 2014. Regulatory challenges in the licensing of a spent nuclear fuel repository in Sweden - 14483. Conference presentation at WM2014 Conference, March 2 - 6, 2014, Phoenix, Arizona, USA. http://www.wmsym.org/archives/2014/papers/14483.pdf - Accessed 16 November 2015. 
Andersson K. 2014. Copper corrosion in nuclear waste disposal: a Swedish case study on stakeholder insight. Bulletin of Science, Technology \& Society, 1-11. DOI: $10.1177 / 0270467613520538$

Auffermann, B., Suomela, P., Kaivo-oja, J., Vehmas, J., Luukkanen, J. 2015. A Final Solution for a Big Challenge. The Governance of Nuclear Waste Disposal in Finland. In Brunnengräber, A., Nucci, M. R., Isodoro Losada, A. M., Mez, L., Schreurs, M. (Eds.). Nuclear Waste Governance. Energy Policy and Climate Protection. DOI 10.1007/978-3-658-08962-7_10. Springer Fachmedien, Wiesbaden.

Beierle, T., Cayford, J. 2002. Democracy in Practice: Public Participation in Environmental Decisions. Routledge, London.

Bendell, J. 2000. Civil regulation: a new form of democratic governance for the global economy, in: J. Bendell (Ed.), Terms for Endearment: Business, NGOs and Sustainable Development. Greenleaf Publishing, Sheffield UK, pp. 239-254.

Bergmans A., Sundqvist G., Kos D., Simmons P. 2014. The participatory turn in radioactive waste management: deliberation and the social-technical divide. Journal of Risk Research, 18(3), 347-363. DOI: 10.1080/13669877.2014.971335.

Bergmans A., Elam M., Kos D., Polič M., Simmons P., Sundqvist G., Walls J. 2008. Wanting the unwanted: effects of public stakeholder involvement in the long term management of radioactive waste and the siting of repository facilities. Final report of the CARL project. https://www.researchgate.net/publication/242767929 Wanting the Unwanted Effects of $\mathrm{Pu}$ blic_and_Stakeholder_Involvement_in the LLong-term_Management_of_Radioactive_Waste and the Siting of Repository Facilities - Accessed 28 December 2015.

Bjällås, U., Persson, I. (2013) Licensing under the Environmental Code and the Nuclear Activities Act of a final repository for spent nuclear fuel. Translation of Report 2011:2. Swedish National Council for Nuclear Waste, Stockholm. http://www.karnavfallsradet.se/sites/default/files/dokument/rapport_2011_2_eng_webb.pdf Accessed 6 October 2016.

Blowers A. 1999. Nuclear waste and landscapes of risk. Landscape Research 24 (3), 241-264. DOI: $10.1080 / 01426399908706562$

Blowers A., Sundqvist G. 2010. Radioactive waste management - technocratic dominance in an age of participation, editorial. Journal of Integrative Environmental Sciences, 7(3), 149-155.

DOI: $10.1080 / 1943815 X .2010 .509042$

von Bonsdorff M. 2007. TVOn ja Ruotsin ydintekniikan kytkennät. ATS Ydintekniikka, 36 (3) 18 20. Available at: http://www.ats-ydintekniikka.fi/lehtiarkisto/ATS\%20Lehti\%202007_3.pdf Accessed 12 January 2015. http://www.skb.se/upload/publications/pdf/R-07-11.pdf Accessed 22 December 2014

COWAM. 2001. Oskarshamn seminar report. 19-21 September 2001. http://www.cowam.com/IMG/pdf/OSKARSHAMN_REPORT.pdf - Accessed 28 December 2015

COWAM. 2003. Nuclear waste management from a local perspective. Reflections for a better governance. COWAM Network 2000/2003. Final report https://curie.ornl.gov/system/files/documents/SEA/COWAM 1 Final Report 2003.pdf Accessed 28 December 2015

Cramér P., Stendahl, S. \& Erhag, T. 2007. Nationellt ansvar för använt kärnbränsle i en utvidgad europeisk union? SKB Rapport R-07-11.

Elam M, Sundqvist G. 2007a. Stakeholder involvement in Swedish nuclear waste management. SKI Report 2007:02, September 2006, Research http://nuwinfo.se/files/ski2007-02.pdf Accessed 28 December 2015 
Elam G, Sundqvist G. 2007b. Six domains of decision for stakeholder involvement in nuclear waste management. CARL thematic report.

http://www.karnavfallsradet.se/sites/default/files/dokument/seminarier/302.pdf - Accessed 28 December 2015.

Elam M, Sundqvist G. 2011. Meddling in Swedish success in nuclear waste management. Environmental Politics 20(2), 246-263. DOI: 10.1080/09644016.2011.551030

Elam M., Lidberg M., Soneryd L., Sundqvist G. 2009. Demonstration and dialogue: mediation in Swedish nuclear waste management. SCORE (Stockholms centrum för forskning om offentlig sektor). http://www.diva-portal.org/smash/get/diva2:214237/FULLTEXT01.pdf - Accessed 28 December 2015.

Elam M., Soneryd L., Sundqvist G. 2010. Demonstrating safety - validating new build: the enduring template of Swedish nuclear waste management. Journal of Integrative Environmental Sciences 7(3), 197-210. DOI: 10.1080/1943815X.2010.506485

Fjaestad M., Hakkarainen P. 2013. Sweden, Finland and the German Energiewende. Friedrich Ebert Stiftung. http://library.fes.de/pdf-files/id/10163.pdf - Accessed 11 August 2016.

Hakkarainen P., Fjaestad M. 2012. Diverging Nuclear Energy Paths: Swedish and Finnish Reactions to the Energiewende. Renewable Energy Law and Policy Review 3 (4), 234-244.

Hanberger A. 2012. Dialogue as nuclear waste management policy: can a Swedish transparency programme legitimise a final decision on spent nuclear fuel? Journal of Integrative Environmental Sciences 9(3), 181-196. DOI: 10.1080/1943815X.2012.701649

Hochstetler, K. 2012. Civil society and the regulatory state of the South: a commentary. Regulation \& Governance 6, 362-370. DOI:10.1111/j.1748-5991.2012.01148.x

Hokkanen P. 2002. Kansalaisosallistumisen muodot ydinjäte-YVA:ssa [The forms of citizen participation in nuclear waste EIA], in: Raittila P., Hokkanen P., Kojo M., Litmanen T. (Eds.), Ydinjäteihme Suomalaisittain [Nuclear waste miracle in a Finnish way]. Tampere University Press, Tampere, pp. 20-35 (in Finnish).

Hokkanen P. 2007. Public participation in environmental assessment. Acta Universitatis Tamperensis 1285, Tampere. (in Finnish).

Hood C, Rothstein H. Baldwin R. 2003. The Government of Risk: Understanding Risk Regulation Regimes. Oxford University Press, Oxford.

Hutler B. M., O'Mahony, J. 2004. The Role of Civil Society Organizations in Regulating Business. Discussion Paper No: 26. ESRC Centre for Analysis of Risk and Regulation. The London School of Economics and Political Science. http://www.lse.ac.uk/accounting/carr/pdf/dps/disspaper26.pdf - Accessed 31 March 2016.

Isaksson R. 2007. Lessons from the EPR construction supervision, in: Transparency of Nuclear Regulatory Activities. Workshop Proceedings Tokyo and Tokai-Mura, Japan 22-24 May 2007. OECD, Nuclear Energy Agency No. 6256, 177-185. http://www.oecdnea.org/nsd/pubs/2007/6256-transparency-nra.pdf - Accessed 10 April 2014.

Jasanoff S. 1985. Peer review in the regulatory process. Science Technology \& Human Values 10(3), 20-32.

Johansson, H.S. 2008. Demokrati på delegation. Lokaliseringen av det svenska kärnavfallet. STS Research Reports No 16. University of Gothenburg. https://gupea.ub.gu.se/bitstream/2077/18689/1/gupea_2077_18689_1.pdf - Accessed 22 December 2015.

Kåberger, T., Swahn, J. 2015. Model or muddle? Governance and management of radioactive waste in Sweden, in: Brunnengräber, A., Di Nucci, M.R., Losada, A.M.I., Mez, L., Schreurs, M.A. (Eds.), Nuclear Waste Governance: An International Comparison, Springer, Wisebaden, pp. 203-225. 
Kainulainen R. (Ed.). 2008. Regulatory control of nuclear safety in Finland. Annual report 2007. STUK-B 92 / JUNE 2008. Radiation and Nuclear Safety Authority, Helsinki. https://www.julkari.fi/bitstream/handle/10024/123230/stuk-b92.pdf?sequence=1- Accessed 28 December 2015

Kari, M. 2015. The first of its kind: Eurajoki as a nuclear community and the site for final disposal of spent nuclear fuel. PhD Dissertation manuscript. University of Jyväskylä, Department of Social Sciences and Philosophy.

Kari M, Kojo M, Litmanen T. 2010. Community divided. Adaptation and aversion towards the spent nuclear fuel repository in Eurajoki and its neighbouring municipalities. University of Jyväskylä. https://jyx.jyu.fi/dspace/handle/123456789/25794 - Accessed 28 December 2015

Kärnavfallsfonden. 2013. Activity report 2013. http://www.karnavfallsfonden.se/download/18.78c1e4631455d30294516341/1399644177994 /Verksamhetsber\%C3\%A4ttelse+2013+engelska.pdf - Accessed 14 January 2015.

Kärnavfallsfond. 2015. Welcome to the Nuclear Waste Fund's web site. http://www.karnavfallsfonden.se/informationinenglish.4.725330be11 efa4b0a3f8000131.html - Accessed 14 January 2015.

Kärnavfallsrådet. 2015. Welcome to the Swedish National Council for Nuclear Waste. Available at: http://www.karnavfallsradet.se/en. - Accessed 14 January 2015.

Klötzer U, Mattsoff, A.-L., Launokari L. 2013. Avoin kirje työ- ja elinkeinoministeriölle, STUK:ille, Posivalle sekä kaikille Suomen hallituksen jäsenille. [Open letter to Ministry of Employment and Economy, STUK, Posiva and all members of government] On behalf of Women Against Nuclear Power, Still No to Nuclear Power Citizen Movement and Women for the Peace in Finland, 10 January 2013.

http://www.naisetrauhanpuolesta.org/Posiva_loppusijoituhakemus_lehdistotiedote_10012013. pdf - accessed 28 December 2015

Kojo M. 2014. Ydinjätepolitiikan osallistava käänne. [The public engagement turn in nuclear waste policy] Acta Universitatis Tamperensis 1987. University of Tampere, Tampere.

http://urn.fi/URN:ISBN:978-951-44-9605-9 (in Finnish) - Accessed 14 January 2015.

Kojo M., Oksa A. 2014a. Adaption of the Swedish KBS disposal concept to Finland: technology transfer case study. In: SOTEC Working Paper. University of Tampere, Tampere. https://tampub.uta.fi/handle/10024/95667 -- Accessed 2 April 2015.

Kojo M., Oksa A. 2014b. The second repository for disposal of spent nuclear fuel in Finland: an analysis of the interests, resources and tactics of the key actors, in: SOTEC Working Paper. University of Tampere: Tampere. http://urn.fi/ URN:ISBN:978-951-44-9514-4 -- Accessed 2 April 2015.

Kojo M., Richardson P. 2012. The added-value approach in siting nuclear waste facilities. Radwaste Solutions 19(1) 38-50.

Koutaniemi P., Reponen H., Salminen P., Sandberg J., Varjoranta T. 2004. Ydinenergialainsäädäntö ja-Hallinto, in: Sandberg J. (Ed.), Ydinturvallisuus. Säteily- ja ydinturvallisuus -kirjasarja, 5. osa. Säteilyturvakeskus: Helsinki, pp. 356-382 (in Finnish).

Krieger K., Rogers M.B. 2010. Green partnerships in Britain's energy sector - classifying nongovernmental organisations and exploring their varying potential to co-operate with energy companies. Environmental Politics 19(6), 910-929. DOI: 10.1080/09644016.2010.518681

Lehtinen J., Isaksson R. 2007. "Secret of radiation" - Journalist training course at STUK. In: Transparency of Nuclear Regulatory Activities. Nuclear Energy Agency Workshop Proceedings. Tokyo and Tokai-Mura, Japan, 22-24 May 2007. NEA No. 6265. OECD: Paris, pp. 133-137.

Lehtonen M. 2010. 'Deliberative decision-making on radioactive waste management in Finland, France and the UK: influence of mixed forms of deliberation in the macro discursive context', 
Journal of Integrative Environmental Sciences, 7: 3, 175-196. DOI: 10.1080/1943815X.2010.506487.

Lidskog R. 1994. The politics of radwaste management: civil society, the economy and the state. Acta Sociologica 37(1), 55-73. DOI: 10.1177/000169939403700104

Lidskog R., Andersson A.-C. 2001. The management of radioactive waste. A description of ten countries. http://www.edram.info/fileadmin/edram/pdf/The_management.pdf - Accessed 8.5.2013.

Lidskog R., Litmanen T. 1997. The Social Shaping of Radwaste Management: the Cases of Sweden and Finland. Current Sociology 45(3), 59-79.

Lidskog R., Sundqvist G. 2004. On the right track? Technology, geology and society in Swedish nuclear waste management. Journal of Risk Research 7(2), 251-268. DOI:

$10.1080 / 1366987042000171924$

Litmanen T. 2010. Nuclear power in societal flux: the renewal of nuclear power in Finland in the context of global concern over energy security. International Electronic Journal of Nuclear Safety and Simulation 1(4), 280-290.

Litmanen T., Kojo M. 2011. Not excluding nuclear power: the dynamics and stability of nuclear power policy arrangements in Finland. Journal of Integrative Environmental Sciences 8(3), 171-194. DOI: 10.1080/1943815X.2011.585652

Litmanen T., Kari M., Vesalainen J., Kojo M. 2014. Socio-technical risk governance through dyadic risk dialogue: copper corrosion as a safety challenge in the geological disposal of spent nuclear fuel, in: SOTEC Working Paper, University of Jyväskylä, Jyväskylä. Available at: http://urn.fi/URN:ISBN:978-951-39-5739-1.

Litmanen T., Kojo, M., Kari M., Vesalainen J. 2016. Does technical risk dialogue entail socioeconomic valuation? The case of scientific dispute over copper corrosion in a spent nuclear fuel disposal project. Forthcoming in: Lehtonen, M, Joly, P-B \& Aparicio, L, (eds) Dealing with uncertainties in socioeconomic evaluation of megaprojects. Routledge, Explorations in Environmental Studies.

MacKerron G., Berghout B. 2009. Learning to listen: institutional change and legitimation in UK radioactive waste policy. Journal of Risk Research, 12(7-8), 989-1008.

May P.J., Jochim A.E. 2013. Policy regime perspectives: policies, politics, and governing. Policy Studies Journal 41(3), 426-452. DOI: 10.1111/psj.12024

MEE (Ministry of Employment and Economy). 2012. Nuclear waste management investigation group submits an interim report to Minister Häkämies. Ministry of Employment and Economy, Press releases: Energy 27.06.2012 10:00. http://www.tem.fi/?89521_m=107098\&l=en\&s=2471 - Accessed 6 May 2015

MEE. 2013. Joint use of know-how on nuclear waste management to be utilized. Ministry of Employment and Economy, Press releases: Energy 10.01.2013 10:30. http://www.tem.fi/?89521_m=109189\&l=en\&s=2471 - Accessed 6 May 2015.

MEE. 2015. Nuclear waste management fund. https://www.tem.fi/en/energy/nuclear_energy/nuclear_energy_administration/nuclear_waste_ management fund - Accessed 28 December 2015.

Meserve R.A. 2009. The global nuclear safety regime. Daedalus 138 (4), 100-111. DOI:10.1162/daed.2009.138.4.100

Michanek G., Söderholm P. 2009. Licensing of nuclear power plants: the case of Sweden in an international comparison. Energy Policy 37, 4086-4097. DOI: 10.1016/j.enpol.2009.04.051

MKG 2016a. Tidplan slutförvar av kärnbränsle m.m. Nacka Tingsrätt. Mark- och miljödomstolen. Tidplan 2015-12-17. Aktbilaga 347, Mål nr M 1333-11, Avdelning 3. http://www.mkg.se/uploads/Aktbilagor/347_Nacka_TR_M_1333-11_Aktbil_347_Tidplan.pdf - Accessed 5 October 2016. 
MKG. 2016b. Majoriteten i Östhammars kommun föreslår en folkomröstning. 15 April 2016. http://www.mkg.se/majoriteten-i-osthammars-kommun-foreslar-en-folkomrostning Accessed 5 October 2016.

Murphy, D.F., Bendell, J. 1999. Partners in Time? Business, NGOs and Sustainable Development. United Nations Research Institute for Social Development, UNRISD Discussion Paper No. 109, August 1999.

http://www.unrisd.org/80256B3C005BCCF9/(httpAuxPages)/259BB13AD57AC8E980256B 61004F9A62/\$file/dp109.pdf - Accessed 16 November 2015

NDA (UK Nuclear Decommissioning Authority). 2010. Brief overview of NGO involvement in the radioactive waste management process in eleven overseas countries. Geological Disposal,

NDA Technical Note no. 12819508, July 2010.

http://www.westcumbriamrws.org.uk/documents/100NGO_involvement_overseas_TN17681.pdf - Accessed 28 July 2015.

NEA (OECD Nuclear Energy Agency). 2000. Stakeholder confidence and radioactive waste disposal. Inauguration, first workshop and meeting of the NEA forum on stakeholder confidence in the area of radioactive waste management. Paris, 28-31 August 2000. http://www.oecd-nea.org/rwm/reports/2000/nea2829.pdf - Accessed 20 April 2015.

NEA. 2009. A common objective, a variety of paths: synthesis and main lessons. Third International Conference on Geological Repositories. Bern, Switzerland 15-17 October 2007. https://www.oecd-nea.org/rwm/reports/2009/6875-icgr2007.pdf - Accessed 28 December 2015.

NEA. 2011. Actual implementation of a spent nuclear fuel repository in Sweden: seizing opportunities. Synthesis of the FSC National Workshop and Community Visit, Östhammar, Sweden, 4-6 May 2011. NEA/RWM/R (2012). Paris: OECD, NEA. https://www.oecdnea.org/rwm/docs/2012/rwm-r2012-2.pdf - Accessed 28 December 2015

NEA. 2013. Stakeholder confidence in radioactive waste management - an annotated glossary of key terms, NEA No. 6988, OECD 2013 https://www.oecd-nea.org/rwm/docs/2013/6988-fscglossary.pdf - Accessed 28 December 2015

NEA. 2014. The Characteristics of an Effective Nuclear Regulator. Nuclear Regulation NEA/CNRA/R(2014)3. OECD NEA No. 7185. http://www.oecdnea.org/nsd/pubs/2014/7185-regulator.pdf - Accessed 6 October 2016.

Newell, P. 2008. Civil society, corporate accountability and the politics of climate change. Global Environmental Politics 8 (3), 122-153. DOI: 10.1162/glep.2008.8.3.122

Norhstedt D. 2010. Do advocacy coalitions matter? Crisis and change in swedish nuclear energy policy. Journal of Public Administration Research Theory 20 (2), 309-333.

DOI:10.1093/jopart/mun038

Nurmi A. Kojo M. \& Litmanen T. 2009. Yleisökysymyksiä vailla vastauksia. Käytetyn ydinpolttoaineen loppusijoituslaitoksen laajennushankkeen yleisötilaisuudet Eurajoella 20082009. Jyväskylän yliopisto, Jyväskylä. https://jyx.jyu.fi/dspace/handle/123456789/44125 — Accessed 22 December 2015

NWTRB (Nuclear Waste Technical Review Board). 2009. Survey of national programs for managing high-level radioactive waste and spent nuclear fuel. A report to Congress and the Secretary of Energy, October 2009. United States Nuclear Waste Technical Review Board. http://www.nwtrb.gov/reports/nwtrb\%20sept\%2009.pdf - Accessed 20 April 2015.

NWTRB. 2011. Technical advancements and issues associated with the permanent disposal of highactivity wastes. Lessons learned from Yucca Mountain and other programs. June 2011. A report to Congress and the Secretary of Energy. United States Nuclear Waste Technical Review Board. http://www.nwtrb.gov/reports/technical\%20lessons.pdf - Accessed 20 April 2015. 
Pellizzoni, L. 2004. Responsibility and environmental governance. Environmental Politics 13 (3): 541-565. DOI:10.1080/0964401042000229034

Persson I. 2011. New legislation in the nuclear field in Sweden. 8 December 2011. Swedish National Council for Nuclear Waste. http://www.burges-salmon.com/INLA_2012/10177.pdf accessed 28 December 2015

Posiva. 2009. In reference to the application for a decision-in-principle submitted to the Government, overall description of an extension to the final disposal facility of spent nuclear fuel to accommodate for the fuel from Olkiluoto 4 plant unit. http://www.posiva.fi/files/514/Posiva_YLPS_en.pdf - accessed 28 December 2015.

Posiva. 2013a. Focus of work at Olkiluoto turns to implementation of final disposal. http://www.posiva.fi/en/media/news/focus_of_work_at_olkiluoto_turns_to_implementation_o f final disposal.1212.news\#.VoLfuMArLBI - accessed 28 December 2015.

Posiva. 2013b. YJH-2012. Nuclear waste management at Olkiluoto and Loviisa power plants: review of current status and future plans for 2013-2015. http://www.posiva.fi/en/databank/publications/nuclear waste management plans and annua 1_reports_(yjh_reports)/yjh-2012_nuclear_waste_management_at_olkiluoto_and loviisa power plants review of current status and future plans for 20132015.2269.xhtml\#.VoLgJsArLBI - accessed 28 December 2015

Posiva. 2015. General Time Schedule for Final Disposal. http://www.posiva.fi/en/final disposal/general time schedule for final disposal\#.Vot1JfmL Qgt - accessed 5 January 2016

Reiman, T., Pietikäinen, E., Kahlbom, U. \& Rollenhagen, C. 2010. Safety Culture in the Finnish and Swedish Nuclear Industries - History and Present. Nordic nuclear safety research, NKS213. NKS Secretariat, Roskilde.

Ringius L. 1997. Environmental NGOs and regime change: the case of ocean dumping of radioactive waste. European Journal of International Relations 3(1), 61-104.

DOI: $10.1177 / 1354066197003001003$

Rosenberg T. 1999. Turhauttavaa teatteria. Loppusijoitus-YVA Loviisa-liikkeen näkökulmasta, in: T. Litmanen, P. Hokkanen, M. Kojo (Eds) Ydinjäte käsissämme. Suomen ydinjätehuolto ja suomalainen yhteiskunta. Jyväskylän yliopisto, SoPhi, Jyväskylä. p. 266-282.

Ruokola E. 2000. Posiva's application for a decision in principle concerning a disposal facility for spent nuclear fuel - STUK's statement and preliminary safety appraisal. Radiation and Nuclear Safety Authority (STUK), Report STUK-B-YTO 198.

SKB. 2010. RD\&D Programme 2010. Programme for research, development and demonstration of methods for the management and disposal of nuclear waste . September 2010. Technical Report TR-10-63. Svensk Kärnbränslehantering AB. http://www.skb.se/upload/publications/pdf/TR-10-63.pdf - accessed 28 December 2015

SSM. 2011a. Review and evaluation of the Swedish Nuclear Fuel and Waste Management Company's RD\&D programme 2010. Statement to the government and summary of the review report. Report number: 2011:10e. Swedish Radiation Safety Authority, Stockholm. https://www.stralsakerhetsmyndigheten.se/Global/Publikationer/Rapport/Avfall-transportfysiskt-skydd/2011/SSM-Rapport-2011-10e.pdf -28 December 2015

SSM. 2011b. The review process. http://www.stralsakerhetsmyndigheten.se/In-English/About-theSwedish-Radiation-Safety-Authority1/Spent-nuclear-fuel-repository/Review-Process/ Accessed 6 October 2016

SSM. 2015. Statement in 2017 concerning the geological repository in Sweden. Translation of debate article in Dagens Nyheter published on 12 February 2015. http://www.stralsakerhetsmyndigheten.se/Global/Engelska/15702\%20Debattartikel\%20DN\%20729608_1_0\%20English.pdf - Accessed 8 January 2016 
Strauss H. 2010. Involving the Finnish public in nuclear facility licensing: participatory democracy and industrial bias. Journal of Integrative Environmental Sciences 7(3), 211-228.

DOI:10.1080/1943815X.2010.506486

Strauss H. 2011. For the good of society. Public participation in the siting of nuclear and hydro power projects in Finland. Universitatis Ouluensis. E Scientiae Rerum Socialium 118. University of Oulu: Oulu.

STUK. 2015. STUK - nuclear waste facility can be built to be safe. 12 February 2015. https://www.stuk.fi/web/en/-/stuk-nuclear-waste-facility-can-be-built-to-be-safe - Accessed 28 December 2015.

STUKLEX. 1999. Government decision on the safety of disposal of spent nuclear fuel. 25.3.1999/478. http://plus.edilex.fi/stuklex/en/lainsaadanto/19990478/ - Accessed 20 April 2015.

STUKLEX. 2015. Nuclear Energy Act of 1987 (11.12.1987/990) http://plus.edilex.fi/stuklex/en/lainsaadanto/19870990 - Accessed 19 May 2015.

Sundqvist G. 2002. The Bedrock of Opinion: Science, Technology and Society in the Siting of High-Level Nuclear Waste. Kluwer Academic Publishers, Dordrecht.

Sundqvist G., Elam M. 2010. Public involvement designed to circumvent public concern? The "participatory turn" in European nuclear activities. Risk, Hazards \& Crisis in Public Policy 1 (4), 203-229. DOI: 10.2202/1944-4079.1046

Sunell M. 2004. Suomalainen ydinvoimapoikkeus, in: Kojo M. (Ed.), Ydinvoima, valta ja vastarinta [Nuclear power, power and resistance]. Like, Helsinki, pp. 179-207.

Swahn J. 2011. Reflections on dialogue and consultation in the process of developing a Swedish repository for spent nuclear fuel. Presentation at the OECD/NEA forum on stakeholder confidence, FSC, at Gimo, May 2011. Swedish NGO Office of Nuclear Waste Review, MKG. http://www.mkg.se/uploads/Synopsis_final_presentation_Johan_Swahn_MKG_FSC_meeting Gimo May 2011.pdf - Accessed 28 December 2015

Tommola A. 2001. Toimittajat ja ydinjäte, in: Raittila P. (Ed.), Mediat Ydinjätettä Hautaamassa: Eri Intressiryhmien Julkisuuteen Pääsy, Dialogi ja Argumentointi Ydinjätteen Loppusijoitusta Koskevassa Keskustelussa 1999-2001. Journalismin tutkimusyksikkö, Tampereen yliopisto, Tampere, p. 81-100.

Vogel D. 2010. The private regulation of global corporate conduct: achievements and limitations. Business \& Society 49(1), 68-87. DOI: 10.1177/0007650309343407

Vuorinen A. 2008. Regulators' role in development of Finnish nuclear waste disposal program. Progress in Nuclear Energy 50(2-6), 674-679. DOI:10.1016/j.pnucene.2007.11.055

Wahlström, B. 1999. Finnish and Swedish practices in nuclear safety. In Misumi, J., Wilpert, B., Miller, R. (eds.) Nuclear Safety: A Human Factors Perspective, Taylor\&Francis: London, 4960.

Wahlström B., Rollenhagen C. 2007. Organisational factors and nuclear safety: issues to address in research and development. Paper presented on the Joint 8th Annual IEEE Conference on Human Factors and Power Plants and 13th Annual Workshop on Human Performance / Root Cause / Trending / Operating Experience / Self Assessment, August 26-31, 2007, Monterey, CA. http://www.bewas.fi/monterey issues.pdf - Accessed 29 April 2015.

Wärnbäck A. 2012. EIA practice: examples of cumulative effects and final disposal of spent nuclear fuel. PhD Thesis. Faculty of Natural Resources and Agricultural Sciences Department of Urban and Rural Development. Swedish University of Agricultural Sciences, Uppsala.

Wärnbäck A., Soneryd L., Hilding-Rydevik T. 2013. Shared practice and converging views in nuclear waste management: long-term relations between implementer and regulator in Sweden. Environment and Planning A 45(9), 2212-2226. DOI: 10.1068/a45305 
Williams S., Heery E., Abbott B. 2011a. The emerging regime of civil regulation in work and employment relations. Human Relations 64 (7), 951-970. DOI: 10.1177/0018726710391687

Williams S., Heery E., Abbott B. 2011b. Civil regulation and HRM: the impact of civil society organisations on the policies and practices of employers. Human Resource Management Journal 21(1), 45-59. DOI: 10.1111/j.1748-8583.2010.00134.x

WNN (World Nuclear News). 2015. Swedish repositry application accepted for review. 18 December 2015. http://www.world-nuclear-news.org/WR-Swedish-repository-applicationaccepted-for-review-1812154.html - Accessed 8.1.2016.

Yli-Kauhaluoma S., Hänninen H. 2014. Tale taming radioactive fears: linking nuclear waste disposal to the "continuum of the good". Public Understanding of Science 23 (3), 316-330. DOI: $10.1177 / 0963662513503773$

Ylönen, M., Litmanen, T., Kojo, M., Lindell, P. 2015. (De)politicisation of Nuclear Power: The Finnish Discussion After Fukushima. Public Understanding of Science. (doi: $10.1177 / 0963662515613678)$

\footnotetext{
${ }^{1}$ We prefer to use the term CSO in the context of SNF decision-making instead of NGO (non-governmental organization), since an NGO is seen as being a negation of governmental organization. Even though both terms are rather loosely used covering a variety of organizational types and the distinction between CSO and NGO is vague, we emphasize the importance of seeing CSOs as: 1) valuable in their own right, i.e. independent citizen organizations, which do not need to be subservient to government; 2) instruments of grassroots democracy, which open up more degrees of freedom to politicize different technological issues.

${ }^{2}$ Vogel (2010) discusses about linkages between civil regulation and the state throughout the article. Notably he pays attention to how 1 ) voluntary private regulation often lean on host-country's laws and also on intergovernmental organizations' regulatory standards, 2) codes of conducts, which have been first introduced by civil society actors, are later adopted by the state, and 3) civil regulation at best compensate for the decreasing regulation capacity of international trade.

${ }^{3}$ NEA uses terms such as 'stakeholder interaction', 'stakeholder involvement', and 'inform the public', but do not use the term 'civil regulation'. NEA's reference "to obtain a broader basis for decisions" can be interpreted as necessity to gain larger value base for decisions, regulation and trustworthiness of regulation.

${ }^{4}$ Swedish acts are published in the Swedish Statute Book, hereinafter referred to as "SFS".

${ }^{5}$ The safety requirements for final disposal are presented in the Government Decision on the safety of disposal of spent nuclear fuel, 1999 (STUKLEX 1999). In Finland the Radiation and Nuclear Safety Authority (STUK) controls the safety of the handling, storing and final disposal of nuclear waste. To ensure appropriate planning of the final disposal of spent nuclear fuel, authorities have set reporting obligations for companies generating nuclear waste. STUK inspects the surveys and technical plans aiming at safe final disposal of waste, and provides feedback to Posiva, who will carry out the project. In Sweden in accordance with the Act (SFS 1984, p. 3) on Nuclear Activities (Nuclear Activities Act) the reactor licensees are obligated to establish the research, development and demonstration program (RD\&D program). In accordance with Section 25 of the Ordinance (1984, p. 14) on Nuclear Activities (Nuclear Activities Ordinance), the Swedish Radiation Safety Authority (SSM) has to review and assess the RD\&D program. For example, the Swedish Nuclear Fuel and Waste Management Company's (SKB) 2010 RD\&D program (SKB 2010) was submitted to the Authority in September 2010 and SSM 2011 report is a review of it (SSM 2011a).

${ }^{6}$ See Auffermann et al. (2015) for doubts concerning the true degree to which this fund indeed is "guaranteed".

731 October 2013 exchange rate provided by Forex Bank: https://www.forex.fi/kurssit/valuuttalaskin/, accessed 3 October 2016.

${ }^{8} 31$ October 2013 exchange rate provided by Forex Bank: https://www.forex.fi/kurssit/valuuttalaskin/, accessed 3 October 2016.

${ }^{9} 31$ October 2013 exchange rate provided by Forex Bank: https://www.forex.fi/kurssit/valuuttalaskin/, accessed 3 October 2016.

${ }^{10} 31$ October 2013 exchange rate provided by Forex Bank: https://www.forex.fi/kurssit/valuuttalaskin/, accessed 3 October 2016.

${ }^{11}$ The function is to assess permissibility before a license application can be considered. The function is political/societal. (Bjällås \& Persson, 2013, 29). "It is clearly stated in the section (of the Environmental Code) that the Government shall consider the permissibility of new activities. The kinds of facilities and activities in question are then enumerated in the section. They are large infrastructural projects that generally have a significant environmental impact at the same time as competing or conflicting interests must be weighed against each other to arrive at the best solution.
} 
In many cases, private interests may be weighed against public interests, or different public interests against each other." (Bjällås \& Persson, 2013, 29)

${ }^{12}$ According to SSM the step-wise review process comprises the following steps: 1. A licence is issued to construct, own and operate the facilities, 2. A licence is issued for commencement of the construction phase, 3 . A licence is issued for test operation, 4. A licence is issued for regular operation, 5. A licence is issued for decommissioning and/or closure (SSM 2011b).

${ }^{13}$ SSM issued its statement as debate article in Dagens Nyheter newspaper at same day that STUK issued its own statement. It is presumable that this was coordinated somehow as SSM referred to STUK's statement.

${ }^{14}$ There aren't any recent research on how journalists perceive Posiva today. However, based on our ongoing research we do know that during the period ranging from 2008 to 2015 nuclear waste has not gained much print media attention.

${ }^{15}$ MKG is the largest beneficiary of the financial support offered to CSOs from the Nuclear Waste Fund.

${ }^{16}$ Sub-political is for Johansson $(2008,388)$ different "political activities in non-parliamentary arenas and the interaction between actors traditionally seen as belonging to the technical and scientific spheres (experts) or the public sphere (politicians, the public, and citizens' organisations) respectively."

${ }^{17}$ Local groups rose up against test drillings, of which residents and stakeholder groups had not been informed, in each site where they were attempted after they received attention in 1980 (Lidskog \& Sundqvist 2004, pp. 161-162; Elam \& Sundqvist 2007a, pp. 19-20; Lidskog 1994, p. 64). It was argued, that final disposal would be possible in most parts of Sweden and SKB started to look for volunteers (Elam \& Sundqvist 2007a, p. 24; 2011, p. 258).

Table 1. Main institutional similarities and differences between the Finnish and Swedish civil regulation approaches for SNF management.

\begin{tabular}{|l|l|}
\hline Similarities & Differences \\
\hline$\bullet \quad \begin{array}{l}\text { Private nuclear waste management } \\
\text { company owned by the nuclear power } \\
\text { industry is responsible for } \\
\text { implementation of final disposal of SNF. }\end{array}$ & $\begin{array}{l}\text { Political decision on construction of a } \\
\text { SNF repository is taken later in the } \\
\text { Swedish licensing process than in the }\end{array}$ \\
\begin{tabular}{lll|} 
Finnish process, in which the Decision- \\
in-Principle on a nuclear facility \\
launches the licensing process.
\end{tabular} \\
\hline $\begin{array}{l}\text { Local council of a proposed host } \\
\text { municipality for a SNF repository is } \\
\text { vested with veto right under law. }\end{array}$ & $\begin{array}{l}\text { In Sweden there are two parallel } \\
\text { licensing procedures, whereas in Finland } \\
\text { the licensing process design is simpler. }\end{array}$ \\
\hline $\begin{array}{l}\text { The EIA process includes public } \\
\text { participation. }\end{array}$ & $\begin{array}{l}\text { Only in Sweden do CSOs have the } \\
\text { possibility to apply for annual funding } \\
\text { from the Nuclear Waste Fund. }\end{array}$ \\
\hline $\begin{array}{l}\text { In both countries community benefit } \\
\text { packages are part of the process, } \\
\text { although the benefits are more generous } \\
\text { in Sweden. }\end{array}$ & $\begin{array}{l}\text { Societal activity towards development } \\
\text { and implementation of public } \\
\text { engagement in SNF disposal is more } \\
\text { frequent in Sweden than in Finland. }\end{array}$ \\
\hline & $\begin{array}{l}\text { Public consultation is part of the R\&D } \\
\text { process of safety analysis in Sweden. }\end{array}$ \\
\hline
\end{tabular}




\begin{tabular}{|l|l|}
\hline & $\begin{array}{l}\text { The Swedish National Council for } \\
\text { Nuclear Waste conducts independent } \\
\text { program oversight whereas the Finnish } \\
\text { regime lacks such as an organization. }\end{array}$ \\
\hline & $\begin{array}{l}\text { Finnish nuclear policy is more } \\
\text { expansionist than the Swedish nuclear } \\
\text { policy. }\end{array}$ \\
\hline
\end{tabular}

\footnotetext{
${ }^{18}$ According to one NGO representative: "An advisory council was going to be created which we saw as a continuation of the dialogue project, but after the first meeting, the environmental organisations were tossed out from this collaboration forum." (COWAM 2001, 45). Quote from another COWAM report seem to verify exclusion of NGOs: "Hence, the environmental NGOs feel they do not have opportunity to get involved, other than to act through local groups in the concerned communities." (COWAM 2003, 19)

${ }^{19} 1999$ exchange rate provided by Bank of Finland Museum: http://apps.rahamuseo.fi/rahanarvolaskin\#FIN, accessed 3 October 2016.

${ }^{20} 1999$ exchange rate provided by Bank of Finland Museum: http://apps.rahamuseo.fi/rahanarvolaskin\#FIN, accessed 3 October 2016.

${ }^{21}$ The Swedish institutional design enable more opportunities to public participation and is more capable of providing opportunities for civil regulation.
} 